\title{
Prevalence of Human Papilloma Virus in Tunisia
}

\author{
Ali Mrabet", MT Khoufi, C Tounsi, R Dhaoui, M Chibani, N Doss \\ From Abstracts from International Symposium HIV and Emerging Infectious Diseases 2014 \\ Marseille, France. 21-23 May 2013
}

\section{Introduction}

Cervical cancer is still a major health problem in Tunisia and over the world. HPV infection may induce malignant transformation of lesions, especially in case of colonization by oncogenic HPV genotypes. Early detection of viral genome by molecular biology in women with normal cytology in cervical screening test (CST) can be a part of a screening policy to improve cancer prevention. Our aim was to evaluate HPV prevalence and genotype distribution in routine CST.

\section{Methods}

It was a prospective study conducted over a six month period (2012, January to June). 665 women were screened by an examination of the cervix, a cervical screening test and a detection of the HPV DNA by PCR. This detection of the high oncogenic risk HPV was made from the cytobrush that was used for the spreading of the cervix cells.

\section{Results}

The mean age was $41.5 \pm 9.1$ years $(20-71$ y). The mean age of the marriage was $24.8 \pm 5$ years $(16-50 \mathrm{y})$. The age of the first pregnancy was $24.8 \pm 5.7$ years (14-48 y). Six percent reported history of genital lesion in their partner. $37 \%$ used or are still using Intra Uterine Device and 48\% used or are still using contraceptive pills. 58\% had never had a routine CST and $27 \%$ had one CST. $65 \%$ of the women reported a history of vaginal discharge, $25 \%$ a genital ulceration and $4.5 \%$ condylomas. The cervix examination showed $51 \%$ of normal cervix, without any clinical macroscopic anomaly. $41 \%$ had a cervix inflammation, $18 \%$ had leucorrhea, $7 \%$ had polypus and 3\% had condylomas. HPV prevalence was $3 \%$.

\section{Conclusion}

Our results showed lower HPV prevalence, probably due to later onset of sexual practice and fewer sexual partners.

Tunisian Military Health General Directorate, Tunis, Tunisia
Published: 23 May 2014

doi:10.1186/1471-2334-14-S2-P95

Cite this article as: Mrabet et al.: Prevalence of Human Papilloma Virus

in Tunisia. BMC Infectious Diseases 2014 14(Suppl 2):P95.
Submit your next manuscript to BioMed Central and take full advantage of:

- Convenient online submission

- Thorough peer review

- No space constraints or color figure charges

- Immediate publication on acceptance

- Inclusion in PubMed, CAS, Scopus and Google Scholar

- Research which is freely available for redistribution
() Biomed Central 